\title{
DYNAMICS OF INTRA-EMS INTEREST RATE LINKAGES
}

\author{
Christopher F. Baum* \\ Associate Professor of Economics \\ Department of Economics \\ Boston College \\ Chestnut Hill, MA 02467 USA
}

\author{
John Barkoulas \\ Assistant Professor of Finance \\ Department of Finance and Quantitative Analysis \\ Georgia Southern University \\ Statesboro, GA 30460 USA
}




\title{
DYNAMICS OF INTRA-EMS INTEREST RATE LINKAGES
}

\author{
Christopher F. Baum \\ Associate Professor of Economics \\ Boston College \\ John Barkoulas \\ Assistant Professor of Finance \\ Georgia Southern University
}

\begin{abstract}
A number of previous studies have questioned the dominant role of Germany within the EMS. These conclusions are often based on empirical findings that the interest rates of EMS member countries are not affected by German interest rates, even in the long run. In this study we demonstrate that intra-EMS interest rate differentials (vis-a-vis Germany) exhibit mean-reverting behavior characterized by long-memory dynamics. In a system incorporating six EMS countries and one non-EMS country (the U.S.), estimates from a fractional error correction model suggest the presence of short-run intra-EMS monetary-policy interdependencies, but validate the German Dominance Hypothesis in the long run.
\end{abstract}




\section{DYNAMICS OF INTRA-EMS INTEREST RATE LINKAGES}

\section{Introduction}

In 1979, the European Monetary System (EMS) began operation, establishing the Exchange Rate Mechanism (ERM) with the original intention of maintaining a system of fixed-but-adjustable exchange rates within Europe. Each country participating was to exhibit symmetric behavior in maintaining the exchange rate arrangement. Since then, however, the popular view is that the system operated in an asymmetric manner, with Germany being the center country and the remaining member countries bearing the burden of adjustment. This view of an asymmetric system with the German central bank conducting monetary policy independently is referred to in the literature as the "German Dominance Hypothesis" (GDH). A direct implication of the GDH is that the interest rates of other EMS member countries are cointegrated with the German interest rate, with the German interest rate playing the leading role.

However, Karfakis and Moschos (1990), Katsimbris and Miller (1993), Hassapis et al. (1999), and Caporale et al. (1996), among others, report evidence that short-term interest rates in EMS countries are not cointegrated with the German interest rate. ${ }^{1}$ The absence of a common trend in the bivariate systems of EMS and German interest rates refutes the monetary-policy objectives of the EMS, and suggests the absence of convergence of European monetary policies. Parallel interest rate movements are expected to be even stronger in a regime of exchange rate discipline, such as the ERM, than in a flexible exchange rate regime. Additionally, the lack of mean-reverting dynamics for the intra-EMS interest rate linkages alludes to the presence of nonstationary risk premia in the EMS currencies relative to the Deutsche mark, which is difficult to justify on theoretical grounds. To account for this evidence of capital-market 
segmentation between the EMS countries and Germany, researchers resorted to explanations based on model misspecification due to an omitted-variable bias, the low power of tests used, and the possibility of structural breaks in the relationships arising from currency realignments.

Katsimbris and Miller (1993) estimate trivariate error-correction models including the U.S. interest rate in the system and, based on Granger causality tests, report negative evidence for the GDH, finding that EMS interest rates respond to each other as well as to the U.S. interest rate. Hassapis et al. (1999) apply the Johansen cointegration methodology to systems of EMS interest rates extended to include the U.S. interest rate. They find that EMS interest rates are cointegrated with the U.S. interest rate but not with the German interest rate. ${ }^{2}$ They identify short-run intra-EMS linkages but, in most cases, they report that German interest rates are caused by, rather than cause, the interest rates of the other EMS countries. ${ }^{3}$

This paper challenges the finding of unit root in the intra-EMS interest rate spreads with Germany as the benchmark country on methodological grounds. Unlike previous studies that consider only integer orders of integration in the long-run relationship among EMS interest rates, we allow for a fractional, long-memory, (co)integrating relationship in those time series. This generalized form of integration avoids the assumption that the potential equilibrium relationships are distributed as either $I(1)$ or $I(0)$ processes and therefore captures a wider range of mean-reverting stochastic behavior. The characteristic of a long-memory process is that its autocorrelation function decays very slowly over time at a hyperbolic rate, contrary to the faster, geometric decay of a stationary ARMA process. ${ }^{4}$

We analyze interest rate linkages in a model containing six EMS countries, Germany, Belgium, France, Ireland, Italy, and the Netherlands, and one non-EMS country, the U.S (as representative of overseas rates). We provide strong evidence that the interest rate differentials relative to Germany are characterized by considerable 
persistence, but they exhibit mean-reverting behavior with long-memory features. Fractional error correction model estimates for the system of interest rates suggest that while monetary policymaking is interdependent among EMS member countries in the short run, the only stochastic trend is that driving the German interest rate. The U.S. interest rate has no independent effect on other EMS interest rates once the German influence is accounted for. GDH is therefore validated as a long run proposition for the EMS era, thus supporting the "credibility" hypothesis that exchange rate arrangements impose discipline on monetary policy behavior of the peripheral countries.

The plan of the paper is as follows. Section 2 deals with analytical issues and the econometric methods employed. Data and empirical results are reported in section 3. We conclude in section 4 with a summary of results and their implications.

\section{Theoretical Issues and Empirical Framework}

\subsection{The analytics of interest rate linkages}

Assuming perfect capital mobility and perfect substitutability of two traded oneperiod bonds denominated in different currencies, arbitrage in international financial markets implies that ${ }^{5}$

$$
f_{t}-s_{t}=i_{t}-i_{t}^{*}
$$

where $f_{t}$ is the log forward rate at time $t$ for delivery at time $t+1, s_{t}$ is the log spot rate, and $i_{t}$ and $i_{t}^{*}$ are the domestic and foreign one-period interest rates, respectively. Equation (1) is the covered interest rate parity relationship. Assuming risk-averse behavior and rational expectations in the foreign exchange market, that is, $f_{t}=E_{t}\left(s_{t+1}\right)+\pi_{t}$ and $s_{t+1}=E_{t}\left(s_{t+1}\right)+u_{t+1}$, equation (1) can be rewritten as

$$
\left[s_{t+1}-s_{t}\right]-u_{t+1}+\pi_{t}=i_{t}-i_{t}^{*}
$$


where $u_{t+1}$ is the rational expectations forecast error at time $t+1$ which is orthogonal to the information set at time $t, \pi_{t}$ is a (time-varying) foreign exchange risk premium, and $E_{t}(\cdot)$ is the mathematical expectations operator conditioned on the information set at time $t$. Nonstationary interest rate differentials reported in previous studies imply nonstationary exchange rate changes and/or nonstationary foreign exchange risk premia (since the rational expectations forecast error $u_{t+1}$, by definition, is an $I(0)$ process). Given the empirical evidence that the spot returns series $s_{t+1}-s_{t}$ is a martingale-difference process (see, inter alia, Meese and Singleton (1982) and Baillie and Bollerslev (1989)), nonstationary exchange rate returns are unlikely. Therefore, nonstationary interest rate differentials should reflect nonstationary foreign exchange risk premia.

In contrast to this prediction, studies by Fama (1984), Hansen and Hodrick (1980), Hodrick and Srivastava (1984), Korajczyk (1985), and Wolff (1987), among others, find evidence consistent with stationary time-varying currency risk premia. ${ }^{6}$ More recently, Shively (2000) provides emphatic evidence supportive of time-varying risk premia evolving as stationary processes in the post-Bretton Woods era. From a theoretical viewpoint, it is difficult to believe that a currency risk premium would follow a nonstationary process, as there is no asset pricing model that predicts stochastic trending behavior for the currency risk premium.,8 Therefore the finding of nonstationary intra-EMS interest rate differentials runs contrary to the theoretical prediction that currency risk premia evolve as stationary stochastic processes.

\subsection{The ARFIMA Model}

We employ the fractional differencing estimation methodology as our modeling framework. The model of an autoregressive fractionally integrated moving average 
process of order $(p, d, q)$, denoted by $\operatorname{ARFIMA}(p, d, q)$, with mean $\mu$, may be written using operator notation as

$$
\Phi(L)(1-L)^{d}\left(y_{t}-\mu\right)=\Theta(L) u_{t}, \quad u_{t} \sim \text { i.i.d. }\left(0, \sigma_{u}^{2}\right)
$$

where $L$ is the backward-shift operator, $\Phi(L)=1-\phi_{1} L-\ldots-\phi_{p} L^{p}$ ， $\Theta(L)=1+\vartheta_{1} L+\ldots+\vartheta_{p} L^{p}$, and $(1-L)^{d}$ is the fractional differencing. The parameter $d$ is allowed to assume any real value. The arbitrary restriction of $d$ to integer values gives rise to the standard autoregressive integrated moving average (ARIMA) model. The stochastic process $y_{t}$ is both stationary and invertible if all roots of $\Phi(L)$ and $\Theta(L)$ lie outside the unit circle and $|d|<0.5$. The process is said to exhibit long-memory behavior for $d \in(0,1)$. For $d \in[0.5,1), y_{t}$ is nonstationary (having an infinite variance) but it is mean reverting. We estimate the fractional parameter using Robinson's (1995) multivariate formulation of the log-periodogram regression estimator (see the Technical Appendix for details of the estimation method).

\subsection{The Fractional Error Correction Model}

To investigate short- and long-run causality effects in a fractionally cointegrated system of variables, a fractional error correction model (FECM) is estimated. Granger (1986) showed that a fractionally cointegrated system of order $C I(d, b)$ has an error representation of the form ${ }^{9}$

$$
\Psi(L)(1-L)^{d} y_{t}=-\gamma\left[1-(1-L)^{b}\right](1-L)^{d-b} z_{t}+c(L) \varepsilon_{t}
$$

where $\Psi(L)$ is a matrix polynomial in the lag operator $L$ with $\Psi(0)$ being the identity matrix, $c(L)$ is a finite polynomial lag, $z_{t}$ is the cointegrating relationship, and $\varepsilon_{t}$ is a white noise error term. If expanded in powers of $L$, the lag function $\left[1-(1-L)^{b}\right]$ has no 
term in $L^{0}$, so only lagged values of the error correction term $z_{t}$ enter in the right hand side of equation (4). When the system variables are individually $I(1)$ stochastic processes (each with $d=1$ ), as is the case here, the FECM representation becomes

$$
\Psi(L)(1-L) y_{t}=-\gamma\left[(1-L)^{1-b}-(1-L)\right] z_{t}+c(L) \varepsilon_{t}
$$

Therefore, in the model in (5) changes in each system variable are regressed on their own lagged changes, lagged changes in the other system variables, and the error correction term $z_{t}^{*}=\left[(1-L)^{1-b}-(1-L)\right] z_{t}$, constructed with $b$ set equal to the point estimate of the fractional differencing parameter for the $z_{t}$ series. Contrary to the standard integer-order ECM, changes in each system variable depend not only on $z t-1$ but on the whole history of the error correction term. ${ }^{10}$

\section{Data and Empirical Analysis}

\subsection{Data and Fractional Integration Test Results}

We perform the analysis on monthly short-term interest rate series, covering the period 1979/04-1998/12, for six member countries of the EMS, Germany, Belgium, France, Ireland, Italy, and the Netherlands, and one non-member country, the U.S. (as representative of overseas rates to the system of EMS interest rates). We analyze the dynamics of intra-EMS short-term interest rate linkages as monetary policy is usually believed to primarily influence short-term interest rates. Therefore such linkages provide an indicator of the synchronization of monetary policies. All data series were obtained from the IMF's International Financial Statistics database, line 60B.

In order to ensure robustness of our findings, we consider several sample periods; for comparability with previous studies, we first examine the subperiod covering 1979/04-1988/11. ${ }^{11}$ To see whether the evidence changed in the period leading 
up to monetary union, we also examine the sample periods ending in 1995/12 and 1998/12.

We estimate fractionally-differenced exponents for the interest rate differential (relative to Germany) series by applying Robinson's (1995) multivariate formulation of the log-periodogram regression estimator. ${ }^{12}$ Since the estimator is applied to the differenced series, a significantly negative estimate for the long-memory parameter indicates mean reversion and a rejection of $I(1)$ behavior for the levels of the interest rate differentials. As panel A in Table 1 reports, the $F$ test for most bandwidth choices fails to reject the null hypothesis that all interest rate differentials share the same order of integration. The common differencing parameter over the subsamples, reported in panel $\mathrm{B}$, is around 0.70 and clearly distinguishable from both zero and unity. Interest rate differentials are nonstationary as their fractional exponent estimates exceed the covariance stationarity threshold value of 0.5 . However, they are mean reverting characterized by hyperbolically declining impulse response weights. This evidence is consistent with uncovered interest parity in its weak form and contrary to the unit-root finding of previous studies.

The question arises as to the sources of the observed persistence in the EMS interest rate differentials vis-à-vis Germany. One source could be the frictions encountered by the EMS countries in their transition efforts to link themselves with the Deutsche mark and become delinked from the U.S. dollar. It could also partially emanate from the gradual removal of capital controls during the 1980s. Another likely explanation is the stochastic behavior of the exchange rate within the band. In a targetzone regime, the interest rate differential can be written as

$$
i_{t}-i_{t}^{*}=E_{t}\left(c_{t+1}-c_{t}\right)+E_{t}\left(x_{t+1}-x_{t}\right),
$$


where $c_{t}$ is the central parity and $x_{t}$ is the proportionate deviation from the central parity. $x_{t}$, informally referred to as the exchange rate within the band, is theoretically mean-reverting (Krugman 1991) and it empirically exhibits strong autocorrelation (Rose and Svensson 1995). Should the exchange rate within the band exhibit long memory, the interest rate spread may inherit such stochastic behavior. Fractionally differenced intra-EMS interest rate spreads could also possibly reflect the presence of strongly dependent risk premia of the EMS currencies relative to the Deutsche mark.

\subsection{Estimation of the Fractional Error Correction Model}

The finding that the interest rates of EMS countries and Germany (together with the U.S. interest rate) form a fractionally cointegrated system (Engle and Granger 1987) with a $(1,-1)$ cointegrating vector implies that the monetary policies of the countries participating in the EMS are interdependent. However, shocks to the system of interest rates have a long-lasting effect, as they dissipate at the slow hyperbolic rate of decay. The mean-reverting behavior of the intra-EMS interest rate spreads (relative to Germany) suggests convergence of EMS monetary policies but it does not provide evidence of the extent of German leadership in determining the monetary policy of the EMS zone. To investigate short- and long-run causality effects in the systems of EMS and German interest rates, we estimate a fractional error correction model (FECM). In accordance with equation (5), we rewrite the FECM as follows ${ }^{13}$

$$
\Delta y_{i, t}=\alpha_{i}+\sum_{j=1}^{7} \sum_{k=1}^{l} \beta_{i j} \Delta y_{i, t-k}+\sum_{j=1}^{q-1} \gamma_{i j} z_{j, t}^{*}+\varepsilon_{i, t}, \quad i=1, \ldots, q
$$

where $y_{i}, i=1,2,3,4,5,6,7=G E R, B E L, F R, I R, I T, N L, U S, l$ is the VAR order, and $z_{j, t}^{*}$ is the fractional error correction term as defined earlier. 
In formulating the FECM in (7), we choose a basis for the cointegration space which is consistent with the conditions of the GDH. The interest rate series form a fractionally cointegrated system of order $C I(d, b)=C I(1,0.3)$ with the six Germanycentered interest rate differentials being fractionally cointegrated processes of order $I(0.7)$. Under the GDH, the interaction among EMS member countries should be characterized by: (i) lack of dependence of German interest rates on the interest rates of other EMS members (the German independence hypothesis) with corresponding restrictions $\beta_{1 j}=\gamma_{1 j}=0, j=2,3,4,5,6$, (ii) dependence of interest rates of EMS members on German interest rates (dependence on Germany) with corresponding restrictions $\beta_{j 1} \neq 0, \gamma_{j 1} \neq 0, j=2,3,4,5,6$, (iii) a lack of dependence of the interest rates of EMS members other than Germany among each other (EMS "insularity") with corresponding restrictions $\beta_{i j}=0, \gamma_{i j}=0, i \neq j,(i, j)=2,3,4,5,6$, and (iv) lack of dependence of EMS interest rates other than Germany on interest rates of countries outside the EMS (the world "insularity" hypothesis), the U.S. in particular, with corresponding restrictions $\beta_{i 7}=0, \gamma_{i 7}=0, i=2,3,4,5,6$. Short-run interdependencies are tested via the statistical significance of lagged interest rate differences (short-run dynamic adjustment parameters) while long-run interdependencies are tested via the statistical significance of the fractional error correction terms (long-run equilibrium parameters). Given the nonstationarity of interest rate levels and their fractional cointegrating relationships, the $\mathrm{GDH}$ is important in its long-run formulation as determined by the significance of the fractional error correction terms $\gamma_{i j}$ in (7).

Table 2 presents estimation results of the FECM for the full system of interest rates under consideration during 1974/11-1988/11, the sample period examined in most previous studies. ${ }^{14}$ German independence is validated as the German interest rates do not depend on other EMS interest rates in either the short- or the long-run (strong exogeneity of the German interest rate relative to the other EMS interest rates). Statistically significant short-run and long-run policy interactions occur among some 
EMS countries, implying rejection of EMS insularity. The world insularity hypothesis is confirmed as the fractional error correction term for the U.S. does not enter significantly in the regression equations for the interest rates of EMS members other than Germany. Thus there is no long-run influence of the U.S. on other EMS interest rates once the German influence is taken into account. We also find a short-run bidirectional feedback relation between the U.S. and Germany and long-run dependence of the German interest rate on the U.S. one (but not vice versa). The only condition of GDH that appears to lack empirical support is (long-run) dependence on Germany for Ireland and the Netherlands, as none of the EMS fractional error terms achieve statistical significance in those regression equations. This can reasonably be attributed to lack of estimation efficiency as, given the small sample size, the lag order for the regression equations of those two countries appears to be overspecified (for the absence of statistical significance of the coefficient estimates). A lag structure of order one in those equations produces serially uncorrelated residual vectors and statistically significant long-run parameters, which is consistent with the condition of long-run dependence on Germany.

Given the FECM results, rejection of EMS insularity (the presence of strong longrun relations among EMS countries) does not invalidate the GDH as only conditions (i), (ii), and (iv) are necessary for GDH. The presence of five fractional cointegrating vectors (i.e., the intra-EMS interest rate spreads relative to Germany) implies the existence of one common stochastic trend within the EMS. Weak exogeneity of German interest rates for the EMS-member cointegrating vectors suggests that they are the driving force of the cointegrated system of EMS interest rates, implying that EMS insularity is not a necessary condition for the GDH. Therefore, from a long-run perspective, there is convergence on the German standard: Germany determines the basic course of monetary policy in the EMS, and each EMS member country has effectively linked its monetary policy to the course of the Bundesbank. 
To examine whether the evidence changed in the 1990s in the run-up to the European monetary union, we also test the GDH over two additional sample periods starting with the inception of the EMS (1974/04) and ending in 1995/11 and 1998/12, respectively. Tables 3 and 4 present the FECM estimates for those sample periods. The evidence is similar to the one for the earlier sample period, characterized by strong asymmetries within the EMS. There is a general feedback among policy actions in the short run. At the 5 per cent level, the German interest rate is weakly exogenous for the cointegrating vectors as there is unidirectional dependence on German interest rates by the other EMS countries in the long run. There is no long-run dependence of Germanother EMS interest rates on the U.S. rate, confirming world insularity. German and U.S. interest rates are long-run independent in the extended sub-periods. Thus the evidence indicates that the EMS operated as a greater Deutschmark area, and GDH is validated as a low-frequency proposition in both sub-samples.

Based on the fractional cointegrating methodology, our findings overall suggest support of long-run dominance and independence of German monetary policy in the (pre-Euro) EMS era. The evidence appears to confirm the credibility argument: the policymakers of EMS countries enhanced their reputation by tying their policies to that of the Bundesbank, which is known to follow a consistent, credible anti-inflation policy. These credibility gains of the peripheral EMS countries appear to have outweighed the costs associated with other considerations, such as domestic growth or international competitiveness. The finding of German dominance may still be relevant in terms of design and conduct of monetary policy within the European monetary union.

\section{Conclusions}

We find evidence suggesting that intra-EMS interest rate linkages with Germany as the center country exhibit long-memory, mean-reverting behavior. This evidence contrasts with previous findings based on restrictive integer-order based 
methodologies. Mean-reverting interest rate differentials imply that monetary policies within the EMS respond to each other. Estimation of fractional error correction models which incorporate the influences of U.S. monetary policy demonstrates that the German Dominance Hypothesis holds in the long-run: there is evidence of intra-EMS low-frequency monetary policy convergence, with Germany playing a hegemonic role. Our findings also imply that the risk premia of EMS currencies as well as the U.S. dollar relative to the Deutsche mark may be expressed as mean-reverting processes, which is justifiable on theoretical grounds. 


\section{References}

Baillie, Richard T. (1996) "Long memory processes and fractional integration in econometrics." Journal of Econometrics, 73, 5-59.

Baillie, Richard T. and Tim Bollerslev. (1989) "Common stochastic trends in a system of exchange rates." Journal of Finance, 44, 167-181.

Bekaert, Geert and Robert Hodrick. (1992) "Characterizing predictable components in excess returns on equity and foreign exchange markets." Journal of Finance, 47, 467-509.

Caporale, Guglielmo, Sarantis Kalyvitis and Nikitas Pittis. (1996) "Interest rate convergence, capital controls, risk premia, and foreign exchange market efficiency in the EMS." Journal of Macroeconomics, 18, 693-714.

Engel, Charles. (1996) “The forward discount anomaly and the risk premium: A survey of recent evidence." Journal of Empirical Finance, 3, 123-192.

Engle, Robert and Clive W.J. Granger. (1987) “Cointegration and error correction: Representation, estimation and testing." Econometrica, 55, 251-276.

Fama, Eugene. (1984) “Forward and spot exchange rates." Journal of Monetary Economics, $14,319-328$.

Granger, Clive W.J. (1986) "Developments in the study of cointegrated economic variables." Oxford Bulletin of Economics and Statistics, 48, 213-228.

Hagen, Jürgen von and Michele Fratianni. (1990) "German dominance in the EMS: Evidence from interest rates." Journal of International Money and Finance, 9, 358375.

Hansen, Lars and Robert Hodrick. (1980) "Forward exchange rates as optimal predictors of future spot rates: An econometric analysis." Journal of Political Economy, 88, 829-853. 
Hassapis, Christis, Nikitas Pittis, and Kyprianos Prodromidis. (1999) "Unit roots and Granger causality in the EMS interest rates: The German dominance hypothesis revisited." Journal of International Money and Finance, 18, 47-73.

Herz, Bernhard and Werner Röger. (1992) "The EMS is a greater Deutschmark area." European Economic Review, 36, 1413-1425.

Hodrick, Robert and Sanjay Srivastava. (1984) "An investigation of risk and return in forward foreign exchange." Journal of International Money and Finance, 3, 5-29.

Karfakis, Costas J. and Demetrios M. Moschos. (1990) "Interest rate linkages within the European Monetary System: A time series analysis." Journal of Money, Credit, and Banking, 22, 388-394.

Katsimbris, George M. and Stephen M. Miller. (1993) "Interest rate linkages within the European Monetary System: Further analysis." Journal of Money, Credit, and Banking, 25, 771-779.

Kirchgässner, Gebhard and Jurgen Wolters. (1993) “Does the DM dominate the Euro market? An empirical investigation." Review of Economics and Statistics, 75, 773778.

Koedijk, Kees G. and Clemens J. M. Kool. (1992) “Dominant interest and inflation differentials within the EMS." European Economic Review, 36, 925-943.

Korajczyk, Robert A. (1985) "The pricing of forward contracts for forward exchange." Journal of Political Economy, 93, 346-368.

Krugman, Paul. (1991) "Target zones and exchange rate dynamics." Quarterly Journal of Economics, 106, 311-325.

Lien, Donald and Yiu Kuen Tse. (1999) "Fractional cointegration and futures hedging." Journal of Futures Markets, 19, 457-474.

Meese, Richard and Kenneth Singleton. (1982) “On unit roots and the empirical modeling of exchange rates." Journal of Finance, 37, 1029-1035. 
Robinson, Peter M. (1995) “Log-periodogram regression of time series with long range dependence." Annals of Statistics, 23, 1048-1072.

Rose, Andrew and Lars Svensson. (1995) "Expected and predicted realignments: The FF/DM exchange rate during the EMS, 1979-93." Scandinavian Journal of Economics, 97, 173-200.

Shively, Philip A. (2000) "Stationary time-varying risk premia in forward foreign exchange rates." Journal of International Money and Finance, 19, 273-288.

Svensson, Lars. (1992) "The foreign exchange risk premium in a target zone with devaluation risk." Journal of International Economics, 33, 21-40.

Van Poeck, André and Johan Van Gombel. (1994) "Dominant interest and inflation differentials within the EMS: A comment." European Economic Review, 38, 16611663.

Wolff, Christian P. (1987) “Forward foreign exchange rates, expected spot rates and premia: A signal extraction approach." Journal of Finance, 42, 395-406. 


\section{Technical Appendix}

We briefly describe Robinson's (1995) multivariate formulation of the logperiodogram regression estimator for the long-memory parameter. Let $Y_{t}$ represent a $M$-dimensional vector with $m^{t h}$ element $Y_{m t}, m=1, \ldots, M$. Assume that $Y_{t}$ has a spectral density matrix $\int_{-\pi}^{\pi} e^{i j \xi} f(\xi) d \xi$, with $(m, \lambda)$ element denoted by $f_{m h}(\xi)$. The periodogram of $Y_{m t}$ is denoted as

$$
I_{m}(\xi)=(2 \pi n)^{-1}\left|\sum_{t=1}^{n} Y_{m t} e^{i t \xi}\right|^{2}, \quad m=1, \ldots, M .
$$

Define $X_{m \lambda}=\log I_{m}\left(\xi_{\lambda}\right)$. The least squares estimate of $G=\left(G_{1}, \ldots G_{M}\right)^{\prime}$ and $d=\left(d_{1}, \ldots d_{M}\right)^{\prime}$ are given by

$$
\left[\begin{array}{c}
\tilde{G} \\
\tilde{d}
\end{array}\right]=\operatorname{vec}\left\{X^{\prime} Z\left(Z^{\prime} Z\right)^{-1}\right\}
$$

where $Z=\left(Z_{1}, \ldots Z_{M}\right)^{\prime}, Z_{\lambda}=\left(1,-2 \log \xi_{\lambda}\right)^{\prime}, X=\left(X_{1}, \ldots X_{M}\right)$, and $X v=\left(X_{m, 1}, \ldots X_{m, v}\right)^{\prime}$ for $\quad v$ periodogram ordinates. Standard errors for $d_{m}$ estimates and for a test of the restriction that two or more of the $d_{m}$ are equal may be derived from the estimated covariance matrix of the least squares coefficients. 
* Corresponding author: Tel.: 617-5523673, fax: 617-5522308, e-mail address: baum@bc.edu. The paper has significantly been improved by comments from three anonymous reviewers. We also thank seminar participants at University of Liverpool, Heriot-Watt University, City University Business School, the University of TennesseeKnoxville, and the Athens Laboratory of Business Administration for their contributions. We are grateful to Tairi Room for expert research assistance.

${ }^{1}$ Kirchgässner and Wolters (1993) provide a notable exception. They report evidence of cointegration in a system of three-month Euro market rates for France, Italy, the Netherlands, and Germany over the 1980-1988 period. However, they find interest rate differentials to be nonstationary.

${ }^{2}$ Contrary to this finding, Kirchgässner and Wolters (1993) fail to find any independent long-run influence of U.S. interest rates on other EMS interest rates once the German rate's influence is taken into account.

${ }^{3}$ Alternative frameworks have been used to analyze the degree of monetary-policy convergence of EMS member countries. Using a more structural model of interest rates, Hagen and Fratianni (1990) report evidence against the GDH. However, their evidence is disputed by Herz and Roger (1992). Koedijk and Kool (1992) argue that the EMS did not function as a Deutschmark zone based on a modified version of principal component analysis. Van Poeck and Gombel (1994) reach the opposite conclusion using cluster analysis.

${ }^{4}$ See Baillie (1996) for a detailed description of fractional differencing and long-memory processes and their applications in economics and finance.

${ }^{5}$ This relationship assumes away transaction costs, bid-ask spreads, capital controls, liquidity risk, political risk, and differential tax treatments. 
${ }^{6}$ Short-term interest rate differentials across countries have been used as approximate determinants of currency risk premia in the empirical literature (see Bekaert and Hodrick 1992, for example).

${ }^{7}$ For example, time-varying risk premia based on equilibrium models reflect second moments of the relevant macroeconomic fundamentals (see (Engel 1996) for a survey). ${ }^{8}$ Additionally, foreign exchange risk premia in target-zone regimes are small (Svensson 1992).

${ }^{9}$ A system of time series $y_{t}=\left\{y_{1 t}, y_{2 t}, \ldots, y_{n t}\right\}$, where each individual series in the system is integrated of order $d$, is said to be cointegrated of order $C I(d, b)$ if the linear combination $z_{t}=\alpha y_{t}, \alpha \neq 0$, the error correction term, is $I(d-b)$ with $b>0$. The $I(1) / I(0)$ paradigm sets $d=1$ and $b=1$.

${ }^{10}$ Lien and Tse (1999) implement a similar fractional error correction model in a bivariate framework.

${ }^{11}$ Karfakis and Moschos (1990), Katsimbris and Miller (1993), and Hassapis et al. (1999) used the same sample period.

${ }^{12}$ We applied integer-order unit root tests to the interest rate differential series, in particular, the ADF-GLS test, in which the $I(1)$ null hypothesis is tested against the alternative of $I(0)$, and the KPSS test, in which stationarity is the null hypothesis to be tested against the alternative of $I(1)$ behavior. The combined results from the two unitroot tests provide conflicting evidence, with neither an $I(1)$ nor an $I(0)$ process adequately describing the stochastic memory of the interest rate differentials. An underparameterized model restricted to integer orders of $d$ may be responsible for the conflicting findings, thus providing motivation for the subsequent fractional- 
differencing testing. These results are not reported here but are available upon request.

${ }^{13}$ Application of the multivariate log-periodogram regression test to our panel of seven interest rate series does not reject the unit-root null, that is, $d_{i}=1, i=1, \ldots, 7$. Consistently with previous studies, interest rate levels appear to be $I(1)$ processes (results are available upon request).

${ }^{14}$ The specification of the VAR order in (7) is based on the SIC criterion (the AIC criterion consistently overestimated the lag order). Following the optimal choice of lag length, the estimated residual vectors from each system equation are tested for serial correlation up to order 12. If the residual vector from any of the system equations is serially correlated, the lag length of the VAR is increased until serially uncorrelated residual vectors are obtained from each system equation. 
Table 1: Robinson Multivariate Log-Periodogram Regression for the Panel of Interest Rate Differentials

\begin{tabular}{|c|c|c|c|}
\hline \multirow[t]{3}{*}{ Bandwidth Choice } & \multicolumn{3}{|c|}{ Robinson Multivariate Results } \\
\hline & \multicolumn{3}{|c|}{$\begin{array}{c}\text { Part } A: F \text { Test } \\
\text { (Panel: } B E L, F R, I R, I T, N L, U S)\end{array}$} \\
\hline & 1988:11 & 1995:12 & 1998:12 \\
\hline$d(0.55)$ & $\begin{array}{c}2.275 \\
(0.057)\end{array}$ & $\begin{array}{c}1.557 \\
(0.178)\end{array}$ & $\begin{array}{c}3.054 \\
(0.012)\end{array}$ \\
\hline$d(0.60)$ & $\begin{array}{c}2.008 \\
(0.084)\end{array}$ & $\begin{array}{c}1.842 \\
(0.108) \\
\end{array}$ & $\begin{array}{c}3.215 \\
(0.008) \\
\end{array}$ \\
\hline$d(0.65)$ & $\begin{array}{c}2.203 \\
(0.057) \\
\end{array}$ & $\begin{array}{l}1.084 \\
(0.370) \\
\end{array}$ & $\begin{array}{l}3.308 \\
(0.006) \\
\end{array}$ \\
\hline$d(0.70)$ & $\begin{array}{c}3.738 \\
(0.003) \\
\end{array}$ & $\begin{array}{c}0.711 \\
(0.615) \\
\end{array}$ & $\begin{array}{l}1.858 \\
(0.102)\end{array}$ \\
\hline \multirow[t]{2}{*}{$d(0.75)$} & $\begin{array}{c}1.649 \\
(0.148) \\
\end{array}$ & $\begin{array}{c}1.109 \\
(0.355) \\
\end{array}$ & $\begin{array}{c}1.753 \\
(0.121) \\
\end{array}$ \\
\hline & \multicolumn{3}{|c|}{ Part B: $\tilde{d}$ Estimates } \\
\hline$\widetilde{d}(0.55)$ & $\begin{array}{c}-0.360 \\
(-3.742)^{* *}\end{array}$ & $\begin{array}{c}-0.294 \\
(-3.500)^{* *} \\
\end{array}$ & $\begin{array}{c}-0.332 \\
(-4.688)^{\star *} \\
\end{array}$ \\
\hline$\widetilde{d}(0.60)$ & $\begin{array}{c}-0.225 \\
(-2.571)^{*} \\
\end{array}$ & $\begin{array}{c}-0.294 \\
(-4.338)^{\star *}\end{array}$ & $\begin{array}{c}-0.342 \\
(-6.006)^{*} \\
\end{array}$ \\
\hline$\widetilde{d}(0.65)$ & $\begin{array}{c}-0.281 \\
(-3.937)^{* *}\end{array}$ & $\begin{array}{c}-0.292 \\
(-5.216)^{* *}\end{array}$ & $\begin{array}{c}-0.287 \\
(-5.957)^{\star *}\end{array}$ \\
\hline$\widetilde{d}(0.70)$ & $\begin{array}{c}-0.221 \\
(-3.611)^{\star *}\end{array}$ & $\begin{array}{c}-0.260 \\
(-5.734)^{* *} \\
\end{array}$ & $\begin{array}{c}-0.265 \\
(-6.235)^{\star *}\end{array}$ \\
\hline$\widetilde{d}(0.75)$ & $\begin{array}{c}-0.128 \\
(-2.418)^{*} \\
\end{array}$ & $\begin{array}{c}-0.170 \\
(-4.176)^{* *} \\
\end{array}$ & $\begin{array}{c}-0.174 \\
(-4.618)^{\star *} \\
\end{array}$ \\
\hline
\end{tabular}

Notes: $\quad B E L, F R, I R, I T, N L, U S$ are first differences in the interest rate differentials relative to

Germany of Belgium, France, Ireland, Italy, the Netherlands, and the U.S., respectively. $\widetilde{d}$ is the common fractional-differencing parameter for the panel of first-differenced interest rate differentials with the corresponding parameter for the levels of interest rate differentials given by $1+\tilde{d} . F$ test is a test of the equality of $\tilde{d}$ estimates for the panel series based on the Robinson multivariate log-periodogram regression method and its $p$-value is given in parentheses. The $t$-statistics are given in parentheses below the $\widetilde{d}$ coefficient estimates. $\widetilde{d}(0.55), \tilde{d}(0.60) \tilde{d}(0.65)$, $\widetilde{d}(0.70)$, and $\widetilde{d}(0.75)$, correspond to estimation sample size (number of Fourier frequencies) $v=T^{0.55}, v=T^{0.60}, v=T^{0.65}, v=T^{0.70}$, and $v=T^{0.75}$, respectively. The superscripts ** * indicate statistical significance at the $1 \%$ and $5 \%$ levels, respectively, for the null hypothesis $\tilde{d}=0$ against the alternative $\widetilde{d} \neq 0$. 
Table 2. VAR Estimation Results of the Fractional Error Correction Model for the System Comprising EMS Interest Rates and the U.S. over the Sample Period 1979/04 - 1988/11

\begin{tabular}{|c|c|c|c|c|c|c|c|}
\hline & & & & $\overline{\text { Country }}$ & & & \\
\hline $\begin{array}{l}\text { Independent } \\
\text { Variables }\end{array}$ & Germany & Belgium & France & Ireland & Italy & Netherlands & U.S. \\
\hline Constant & $\begin{array}{c}-0.047 \\
(0.047)\end{array}$ & $\begin{array}{l}-0.034 \\
(0.051)\end{array}$ & $\begin{array}{c}0.023 \\
(0.071)\end{array}$ & $\begin{array}{c}0.010 \\
(0.148)\end{array}$ & $\begin{array}{c}0.002 \\
(0.061)\end{array}$ & $\begin{array}{c}0.004 \\
(0.081)\end{array}$ & $\begin{array}{l}-0.026 \\
(0.027)\end{array}$ \\
\hline$\sum \Delta G E R_{t-j}$ & $\begin{array}{c}0.586 \\
(0.055)^{*}\end{array}$ & $\begin{array}{l}-0.117 \\
(0.980)\end{array}$ & $\begin{array}{c}-0.981 \\
(0.047)^{* *}\end{array}$ & $\begin{array}{c}0.379 \\
(0.756)\end{array}$ & $\begin{array}{l}-0.374 \\
(0.674)\end{array}$ & $\begin{array}{c}0.218 \\
(0.775)\end{array}$ & $\begin{array}{c}-0.020 \\
(0.000)^{* * *}\end{array}$ \\
\hline$\sum \Delta B E L_{t-j}$ & $\begin{array}{c}-0.002 \\
(0.982)\end{array}$ & $\begin{array}{c}0.110 \\
(0.026)^{* *}\end{array}$ & $\begin{array}{c}-0.053 \\
(0.904)\end{array}$ & $\begin{array}{c}0.184 \\
(0.411)\end{array}$ & $\begin{array}{c}0.130 \\
(0.876)\end{array}$ & $\begin{array}{c}-0.031 \\
(0.201)\end{array}$ & $\begin{array}{l}-0.206 \\
(0.701)\end{array}$ \\
\hline$\sum \Delta F R_{t-j}$ & $\begin{array}{c}0.152 \\
(0.626)\end{array}$ & $\begin{array}{c}0.041 \\
(0.757)\end{array}$ & $\begin{array}{c}0.543 \\
(0.005)^{* * *}\end{array}$ & $\begin{array}{c}0.162 \\
(0.629)\end{array}$ & $\begin{array}{c}-0.186 \\
(0.556)\end{array}$ & $\begin{array}{c}0.493 \\
(0.200)\end{array}$ & $\begin{array}{c}0.585 \\
(0.014)^{* *}\end{array}$ \\
\hline$\sum \Delta I R_{t-j}$ & $\begin{array}{c}0.130 \\
(0.316)\end{array}$ & $\begin{array}{c}0.071 \\
(0.215)\end{array}$ & $\begin{array}{l}0.026 \\
(0.791)\end{array}$ & $\begin{array}{c}0.440 \\
(0.003)^{* * *}\end{array}$ & $\begin{array}{c}0.126 \\
(0.537)\end{array}$ & $\begin{array}{l}-0.019 \\
(0.991)\end{array}$ & $\begin{array}{c}0.105 \\
(0.117)\end{array}$ \\
\hline$\sum \Delta I T_{t-j}$ & $\begin{array}{l}-0.205 \\
(0.102)\end{array}$ & $\begin{array}{c}0.007 \\
(0.576)\end{array}$ & $\begin{array}{c}-0.267 \\
(0.090)^{*}\end{array}$ & $\begin{array}{l}-0.081 \\
(0.131)\end{array}$ & $\begin{array}{c}0.393 \\
(0.059)^{*}\end{array}$ & $\begin{array}{c}0.028 \\
(0.879)\end{array}$ & $\begin{array}{l}-0.199 \\
(0.653)\end{array}$ \\
\hline$\sum \Delta N L_{t-j}$ & $\begin{array}{c}0.091 \\
(0.522)\end{array}$ & $\begin{array}{l}-0.078 \\
(0.454)\end{array}$ & $\begin{array}{c}0.598 \\
(0.129)\end{array}$ & $\begin{array}{l}-0.423 \\
(0.809)\end{array}$ & $\begin{array}{c}0.022 \\
(0.899)\end{array}$ & $\begin{array}{l}-0.000 \\
(0.926)\end{array}$ & $\begin{array}{l}-0.186 \\
(0.461)\end{array}$ \\
\hline$\sum \Delta U S_{t-j}$ & $\begin{array}{c}-0.510 \\
(0.012)^{* *}\end{array}$ & $\begin{array}{c}-0.148 \\
(0.282)\end{array}$ & $\begin{array}{c}0.394 \\
(0.184)\end{array}$ & $\begin{array}{l}-0.100 \\
(0.976)\end{array}$ & $\begin{array}{l}-0.128 \\
(0.562)\end{array}$ & $\begin{array}{l}-0.400 \\
(0.129)\end{array}$ & $\begin{array}{c}0.154 \\
(0.009)^{* * *}\end{array}$ \\
\hline
\end{tabular}




\begin{tabular}{|c|c|c|c|c|c|c|c|}
\hline$z_{t, B E L}^{*}$ & $\begin{array}{c}0.059 \\
(0.461)\end{array}$ & $\begin{array}{c}-0.971 \\
(0.483)^{* *}\end{array}$ & $\begin{array}{l}-0.429 \\
(0.664)\end{array}$ & $\begin{array}{c}0.411 \\
(1.381)\end{array}$ & $\begin{array}{c}-0.888 \\
(0.572)\end{array}$ & $\begin{array}{l}-0.315 \\
(0.758)\end{array}$ & $\begin{array}{c}0.210 \\
(0.347)\end{array}$ \\
\hline$z_{t F R}^{*}$ & -0.035 & -0.143 & -1.724 & -0.185 & 0.866 & -0.164 & -0.342 \\
\hline${ }^{2} t, F R$ & $(0.451)$ & $(0.466)$ & $(0.648)^{* * *}$ & (1.349) & $(0.559)$ & $(0.740)$ & $(0.461)$ \\
\hline$z_{t, I R}^{*}$ & $\begin{array}{l}-0.240 \\
(0.198)\end{array}$ & $\begin{array}{l}-0.157 \\
(0.210)\end{array}$ & $\begin{array}{c}0.151 \\
(0.285)\end{array}$ & $\begin{array}{l}-0.880 \\
(0.593)\end{array}$ & $\begin{array}{l}-0.265 \\
(0.246)\end{array}$ & $\begin{array}{c}0.128 \\
(0.325)\end{array}$ & $\begin{array}{c}-0.244 \\
(0.129)^{*}\end{array}$ \\
\hline$z_{t, I T}^{*}$ & $\begin{array}{c}0.120 \\
(0.322)\end{array}$ & $\begin{array}{c}0.454 \\
(0.339)\end{array}$ & $\begin{array}{c}0.770 \\
(0.463)\end{array}$ & $\begin{array}{c}0.353 \\
(0.963)\end{array}$ & $\begin{array}{c}-0.742 \\
(0.399)^{*}\end{array}$ & $\begin{array}{l}-0.517 \\
(0.529)\end{array}$ & $\begin{array}{c}0.223 \\
(0.287)\end{array}$ \\
\hline$z_{t, N L}^{*}$ & $\begin{array}{c}0.736 \\
(0.534)\end{array}$ & $\begin{array}{l}-0.216 \\
(0.554)\end{array}$ & $\begin{array}{c}-1.633 \\
(0.768)^{* *}\end{array}$ & $\begin{array}{c}0.366 \\
(1.598)\end{array}$ & $\begin{array}{c}-0.810 \\
(0.662)\end{array}$ & $\begin{array}{l}-0.797 \\
(0.877)\end{array}$ & $\begin{array}{c}0.300 \\
(0.502)\end{array}$ \\
\hline$z_{t, U S}^{*}$ & $\begin{array}{c}1.107 \\
(0.425)^{* *}\end{array}$ & $\begin{array}{c}0.417 \\
(0.450)\end{array}$ & $\begin{array}{c}-0.504 \\
(0.612)\end{array}$ & $\begin{array}{c}-0.262 \\
(1.273)\end{array}$ & $\begin{array}{c}0.503 \\
(0.527)\end{array}$ & $\begin{array}{c}1.063 \\
(0.698)\end{array}$ & $\begin{array}{c}0.095 \\
(0.203)\end{array}$ \\
\hline$R^{2}$ & 0.272 & 0.157 & 0.280 & 0.040 & 0.141 & 0.154 & 0.131 \\
\hline$B P(12)$ & $\begin{array}{c}8.305 \\
(0.760)\end{array}$ & $\begin{array}{c}10.929 \\
(0.535)\end{array}$ & $\begin{array}{c}21.018 \\
(0.050)\end{array}$ & $\begin{array}{c}9.404 \\
(0.668)\end{array}$ & $\begin{array}{c}6.117 \\
(0.910)\end{array}$ & $\begin{array}{c}6.124 \\
(0.909)\end{array}$ & $\begin{array}{c}10.161 \\
(0.601)\end{array}$ \\
\hline$A R C H(4)$ & $\begin{array}{c}0.200 \\
(0.995)\end{array}$ & $\begin{array}{c}1.458 \\
(0.833)\end{array}$ & $\begin{array}{l}17.654 \\
(0.001)\end{array}$ & $\begin{array}{c}1.280 \\
(0.864)\end{array}$ & $\begin{array}{c}1.311 \\
(0.859)\end{array}$ & $\begin{array}{c}1.929 \\
(0.748)\end{array}$ & $\begin{array}{c}8.123 \\
(0.087)\end{array}$ \\
\hline
\end{tabular}

Notes: $\triangle G E R, \triangle B E L, \triangle F R, \triangle I R, \triangle I T, \triangle N L$, and $\triangle U S$ are first differences in the interest rates of Germany, Belgium, France, Ireland, Italy, the Netherlands, and the U.S., respectively. The vector autoregression (VAR) order $j$ of the system is two. $z_{t, B E}^{*}=\left[(1-L)^{1-b}-(1-L)\right] z t, B E$ is the fractional error correction term corresponding to the interest rate differential of Belgium relative to Germany $z t, B E$ and $1-b$ is the estimated fractional exponent for $z t, B E$. The error correction terms are similarly defined for the other countries. For the short-run parameters (lagged first differences in interest rates), the coefficient estimate given is the sum of lagged coefficients and the marginal significance of the $F$ statistic that all lagged coefficients are jointly zero is given in parentheses. For the long-run variables (error correction terms), the numbers in parentheses are the standard errors of the coefficient estimates.

$R^{2}$ is the adjusted coefficient of determination.

$B P(12)$ is the Box-Pierce $Q$-test statistic for autocorrelation of order 12 in the regression residuals. Marginal significance levels are given in parentheses.

$A R C H(4)$ is Engle's LM test for ARCH effects of order 4.

The superscripts ${ }^{* * *},{ }^{* *},{ }^{*}$ indicate statistical significance at the $1 \%, 5 \%$, and $10 \%$ significance levels, respectively. 
Table 3. VAR Estimation Results of the Fractional Error Correction Model for the System Comprising EMS Interest Rates and the U.S. over the Sample Period 1979/04 - 1995/12

\begin{tabular}{|c|c|c|c|c|c|c|c|}
\hline & & & & "Country & & & \\
\hline $\begin{array}{l}\text { Independent } \\
\text { Variables }\end{array}$ & Germany & Belgium & France & Ireland & Italy & Netherlands & U.S. \\
\hline Constant & $\begin{array}{c}-0.012 \\
(0.022)\end{array}$ & $\begin{array}{c}-0.068 \\
(0.034)^{*}\end{array}$ & $\begin{array}{c}-0.072 \\
(0.036)^{* *}\end{array}$ & $\begin{array}{c}-0.222 \\
(0.176)\end{array}$ & $\begin{array}{c}-0.014 \\
(0.052)\end{array}$ & $\begin{array}{c}0.003 \\
(0.035)\end{array}$ & $\begin{array}{c}-0.028 \\
(0.035)\end{array}$ \\
\hline$\sum \Delta G E R_{t-j}$ & $\begin{array}{c}-0.052 \\
(0.028)^{* *}\end{array}$ & $\begin{array}{c}0.005 \\
(0.679)\end{array}$ & $\begin{array}{l}-0.009 \\
(0.943)\end{array}$ & $\begin{array}{c}0.706 \\
(0.211)\end{array}$ & $\begin{array}{l}-0.444 \\
(0.826)\end{array}$ & $\begin{array}{l}-0.091 \\
(0.868)\end{array}$ & $\begin{array}{c}0.016 \\
(0.001)^{* * *}\end{array}$ \\
\hline$\sum \Delta B E L_{t-j}$ & $\begin{array}{l}-0.187 \\
(0.262)\end{array}$ & $\begin{array}{c}0.574 \\
(0.000)^{* * *}\end{array}$ & $\begin{array}{c}-0.039 \\
(0.795)\end{array}$ & $\begin{array}{l}-1.057 \\
(0.735)\end{array}$ & $\begin{array}{c}0.425 \\
(0.497)\end{array}$ & $\begin{array}{c}-0.211 \\
(0.429)\end{array}$ & $\begin{array}{c}-0.228 \\
(0.688)\end{array}$ \\
\hline$\sum \Delta F R_{t-j}$ & $\begin{array}{c}0.443 \\
(0.000)^{* * *}\end{array}$ & $\begin{array}{l}-0.294 \\
(0.266)\end{array}$ & $\begin{array}{c}1.003 \\
(0.001)^{* * *}\end{array}$ & $\begin{array}{c}2.474 \\
(0.211)\end{array}$ & $\begin{array}{l}-0.162 \\
(0.979)\end{array}$ & $\begin{array}{c}0.122 \\
(0.279)\end{array}$ & $\begin{array}{c}0.543 \\
(0.042)^{* *}\end{array}$ \\
\hline$\sum \Delta I R_{t-j}$ & $\begin{array}{c}0.044 \\
(0.687)\end{array}$ & $\begin{array}{c}0.142 \\
(0.012)^{* *}\end{array}$ & $\begin{array}{c}-0.091 \\
(0.032)^{* *}\end{array}$ & $\begin{array}{c}1.319 \\
(0.000)^{* * *}\end{array}$ & $\begin{array}{c}0.074 \\
(0.140)\end{array}$ & $\begin{array}{c}-0.046 \\
(0.819)\end{array}$ & $\begin{array}{c}0.118 \\
(0.138)\end{array}$ \\
\hline$\sum \Delta I T_{t-j}$ & $\begin{array}{l}-0.064 \\
(0.214)\end{array}$ & $\begin{array}{c}-0.293 \\
(0.354)\end{array}$ & $\begin{array}{c}-0.443 \\
(0.051)^{*}\end{array}$ & $\begin{array}{c}-1.851 \\
(0.000)^{* * *}\end{array}$ & $\begin{array}{c}0.119 \\
(0.983)\end{array}$ & $\begin{array}{c}0.278 \\
(0.500)\end{array}$ & $\begin{array}{l}-0.164 \\
(0.800)\end{array}$ \\
\hline$\sum \Delta N L_{t-j}$ & $\begin{array}{c}0.166 \\
(0.010)^{* *}\end{array}$ & $\begin{array}{c}0.106 \\
(0.255)\end{array}$ & $\begin{array}{c}-0.043 \\
(0.579)\end{array}$ & $\begin{array}{c}-1.258 \\
(0.311)\end{array}$ & $\begin{array}{c}0.107 \\
(0.816)\end{array}$ & $\begin{array}{c}0.397 \\
(0.081)^{*}\end{array}$ & $\begin{array}{l}-0.218 \\
(0.559)\end{array}$ \\
\hline$\sum \Delta U S_{t-j}$ & $\begin{array}{c}0.019 \\
(0.091)^{*}\end{array}$ & $\begin{array}{c}-0.098 \\
(0.806)\end{array}$ & $\begin{array}{c}0.067 \\
(0.652)\end{array}$ & $\begin{array}{l}-0.033 \\
(0.284)\end{array}$ & $\begin{array}{c}0.125 \\
(0.315)\end{array}$ & $\begin{array}{c}0.252 \\
(0.081)^{*}\end{array}$ & $\begin{array}{c}0.170 \\
(0.021)^{* *}\end{array}$ \\
\hline
\end{tabular}




\begin{tabular}{|c|c|c|c|c|c|c|c|}
\hline$z_{t, B E L}^{*}$ & $\begin{array}{c}0.296 \\
(0.244)\end{array}$ & $\begin{array}{c}-1.063 \\
(0.365)^{* * *}\end{array}$ & $\begin{array}{c}0.136 \\
(0.385)\end{array}$ & $\begin{array}{c}1.081 \\
(1.877)\end{array}$ & $\begin{array}{c}-1.001 \\
(0.561)^{*}\end{array}$ & $\begin{array}{c}0.354 \\
(0.373)\end{array}$ & $\begin{array}{c}0.232 \\
(0.376)\end{array}$ \\
\hline$z_{t, F R}^{*}$ & $\begin{array}{l}-0.595 \\
0.348) *\end{array}$ & 0.320 & $\begin{array}{l}-2.577 \\
548) * * *\end{array}$ & -3.228 & 0.986 & 0.002 & -0.174 \\
\hline$z_{t, I R}^{*}$ & $\begin{array}{c}(0.348)^{*} \\
-0.122 \\
(0.092)\end{array}$ & $\begin{array}{c}(0.511) \\
-0.232 \\
(0.139) *\end{array}$ & $\begin{array}{c}(0.548)^{* * *} \\
0.327 \\
(0.146)^{* *}\end{array}$ & $\begin{array}{c}(2.669) \\
-3.384 \\
(0.712)^{* * *}\end{array}$ & $\begin{array}{c}(0.798) \\
-0.306 \\
(0.213)\end{array}$ & $\begin{array}{c}(0.531) \\
0.125 \\
(0.141)\end{array}$ & $\begin{array}{c}(0.535) \\
-0.265 \\
(0.142)^{*}\end{array}$ \\
\hline$z_{t, I T}^{*}$ & $\begin{array}{c}0.064 \\
(0.237)\end{array}$ & $\begin{array}{c}0.394 \\
(0.352)\end{array}$ & $\begin{array}{c}1.055 \\
(0.374)^{* * *}\end{array}$ & $\begin{array}{c}4.899 \\
(1.822)^{* * *}\end{array}$ & $\begin{array}{l}-0.537 \\
(0.545)\end{array}$ & $\begin{array}{l}-0.496 \\
(0.362)\end{array}$ & $\begin{array}{c}0.138 \\
(0.365)\end{array}$ \\
\hline$z_{t, N L}^{*}$ & $\begin{array}{c}0.214 \\
(0.356)\end{array}$ & $\begin{array}{c}-0.117 \\
(0.528)\end{array}$ & $\begin{array}{l}-0.342 \\
(0.562)\end{array}$ & $\begin{array}{c}3.022 \\
(2.733)\end{array}$ & $\begin{array}{l}-0.490 \\
(0.817)\end{array}$ & $\begin{array}{c}-1.060 \\
(0.544)^{*}\end{array}$ & $\begin{array}{c}0.360 \\
(0.548)\end{array}$ \\
\hline$z_{t, U S}^{*}$ & $\begin{array}{c}0.107 \\
(0.152)\end{array}$ & $\begin{array}{c}-0.044 \\
(0.230)\end{array}$ & $\begin{array}{c}0.055 \\
(0.240)\end{array}$ & $\begin{array}{c}-1.061 \\
(1.169)\end{array}$ & $\begin{array}{c}0.006 \\
(0.349)\end{array}$ & $\begin{array}{l}-0.135 \\
(0.232)\end{array}$ & $\begin{array}{c}0.058 \\
(0.234)\end{array}$ \\
\hline$R^{2}$ & 0.297 & 0.183 & 0.212 & 0.550 & 0.033 & 0.175 & 0.120 \\
\hline$B P(12)$ & $\begin{array}{r}10.412 \\
(0.579)\end{array}$ & $\begin{array}{r}11.223 \\
(0.509)\end{array}$ & $\begin{array}{r}10.668 \\
(0.557)\end{array}$ & $\begin{array}{c}7.041 \\
(0.854)\end{array}$ & $\begin{array}{r}11.567 \\
(0.480)\end{array}$ & $\begin{array}{r}15.186 \\
(0.231)\end{array}$ & $\begin{array}{r}10.424 \\
(0.578)\end{array}$ \\
\hline$A R C H(4)$ & $\begin{array}{c}2.126 \\
(0.712)\end{array}$ & $\begin{array}{c}0.403 \\
(0.982)\end{array}$ & $\begin{array}{c}0.336 \\
(0.987)\end{array}$ & $\begin{array}{c}1.242 \\
(0.871)\end{array}$ & $\begin{array}{c}8.920 \\
(0.063)\end{array}$ & $\begin{array}{c}5.290 \\
(0.258)\end{array}$ & $\begin{array}{c}3.786 \\
(0.435)\end{array}$ \\
\hline
\end{tabular}

Notes: See notes in Table 2 for explanation of table. The vector autoregression (VAR) order $j$ of the system is three. For the short-run parameters (lagged first differences in interest rates), the coefficient estimate given is the sum of lagged coefficients and the marginal significance of the $F$ statistic that all lagged coefficients are jointly zero is given in parentheses. For the long-run variables (error correction terms), the numbers in parentheses are the standard errors of the coefficient estimates.

$R^{2}$ is the adjusted coefficient of determination.

$B P(12)$ is the Box-Pierce $Q$ - test statistic for autocorrelation of order 12 in the regression residuals. Marginal significance levels are given in parentheses.

$A R C H(4)$ is Engle's LM test for ARCH effects of order 4

The superscripts ${ }^{* * *},{ }^{* *},{ }^{*}$ indicate statistical significance at the $1 \%, 5 \%$, and $10 \%$ significance levels, respectively. 
Table 4. VAR Estimation Results of the Fractional Error Correction Model for the System Comprising EMS Interest Rates and the U.S. over the Sample Period 1979/04 - 1998/12

\begin{tabular}{|c|c|c|c|c|c|c|c|}
\hline & & & & Country & & & \\
\hline $\begin{array}{l}\text { Independent } \\
\text { Variables }\end{array}$ & Germany & Belgium & France & Ireland & Italy & Netherlands & U.S. \\
\hline Constant & $\begin{array}{l}-0.019 \\
(0.018)\end{array}$ & $\begin{array}{c}-0.052 \\
(0.027)^{*}\end{array}$ & $\begin{array}{c}-0.072 \\
(0.029) * *\end{array}$ & $\begin{array}{l}-0.060 \\
(0.139)\end{array}$ & $\begin{array}{l}-0.059 \\
(0.042)\end{array}$ & $\begin{array}{l}-0.010 \\
(0.027)\end{array}$ & $\begin{array}{c}-0.028 \\
(0.035)\end{array}$ \\
\hline$\sum \Delta G E R_{t-j}$ & $\begin{array}{c}-0.022 \\
(0.029) * *\end{array}$ & $\begin{array}{l}-0.051 \\
(0.600)\end{array}$ & $\begin{array}{c}0.130 \\
(0.887)\end{array}$ & $\begin{array}{c}0.300 \\
(0.163)\end{array}$ & $\begin{array}{l}-0.258 \\
(0.878)\end{array}$ & $\begin{array}{l}-0.102 \\
(0.802)\end{array}$ & $\begin{array}{c}0.016 \\
(0.001)^{* * * *}\end{array}$ \\
\hline$\sum \Delta B E L_{t-j}$ & $\begin{array}{l}-0.179 \\
(0.333)\end{array}$ & $\begin{array}{c}0.551 \\
(0.000)^{* * *}\end{array}$ & $\begin{array}{l}-0.117 \\
(0.646)\end{array}$ & $\begin{array}{c}-0.911 \\
(0.730)\end{array}$ & $\begin{array}{c}0.374 \\
(0.528)\end{array}$ & $\begin{array}{l}-0.209 \\
(0.409)\end{array}$ & $\begin{array}{c}-0.228 \\
(0.688)\end{array}$ \\
\hline$\sum \Delta F R_{t-j}$ & $\begin{array}{c}0.411 \\
(0.000)^{* * *}\end{array}$ & $\begin{array}{l}-0.321 \\
(0.173)\end{array}$ & $\begin{array}{c}0.745 \\
(0.006)^{* * *}\end{array}$ & $\begin{array}{c}2.558 \\
(0.106)\end{array}$ & $\begin{array}{l}-0.211 \\
(0.889)\end{array}$ & $\begin{array}{c}0.157 \\
(0.166)\end{array}$ & $\begin{array}{c}0.543 \\
(0.042)^{* *}\end{array}$ \\
\hline$\sum \Delta I R_{t-j}$ & $\begin{array}{c}0.050 \\
(0.605)\end{array}$ & $\begin{array}{c}0.136 \\
(0.007)^{* * *}\end{array}$ & $\begin{array}{c}-0.066 \\
(0.008)^{* * *}\end{array}$ & $\begin{array}{c}1.222 \\
(0.000)^{* * *}\end{array}$ & $\begin{array}{c}0.106 \\
(0.070) *\end{array}$ & $\begin{array}{l}-0.044 \\
(0.805)\end{array}$ & $\begin{array}{c}0.118 \\
(0.138)\end{array}$ \\
\hline$\sum \Delta I T_{t-j}$ & $\begin{array}{c}-0.077 \\
(0.160)\end{array}$ & $\begin{array}{l}-0.173 \\
(0.486)\end{array}$ & $\begin{array}{c}-0.191 \\
(0.162)\end{array}$ & $\begin{array}{c}-1.414 \\
(0.000)^{* * *}\end{array}$ & $\begin{array}{c}0.017 \\
(0.998)\end{array}$ & $\begin{array}{c}0.219 \\
(0.481)\end{array}$ & $\begin{array}{l}-0.164 \\
(0.800)\end{array}$ \\
\hline$\sum \Delta N L_{t-j}$ & $\begin{array}{c}0.154 \\
(0.020)^{* *}\end{array}$ & $\begin{array}{c}0.140 \\
(0.199)\end{array}$ & $\begin{array}{l}-0.103 \\
(0.510)\end{array}$ & $\begin{array}{l}-0.966 \\
(0.290)\end{array}$ & $\begin{array}{c}0.017 \\
(0.711)\end{array}$ & $\begin{array}{c}0.380 \\
(0.070)^{*}\end{array}$ & $\begin{array}{l}-0.218 \\
(0.559)\end{array}$ \\
\hline$\sum \Delta U S_{t-j}$ & $\begin{array}{c}0.035 \\
(0.116)\end{array}$ & $\begin{array}{l}-0.140 \\
(0.649)\end{array}$ & $\begin{array}{c}0.075 \\
(0.752)\end{array}$ & $\begin{array}{l}-0.540 \\
(0.258)\end{array}$ & $\begin{array}{c}0.252 \\
(0.280)\end{array}$ & $\begin{array}{c}0.286 \\
(0.031)^{* *}\end{array}$ & $\begin{array}{c}0.170 \\
(0.021)^{* *}\end{array}$ \\
\hline
\end{tabular}




\begin{tabular}{|c|c|c|c|c|c|c|c|}
\hline$z_{t, B E L}^{*}$ & $\begin{array}{c}0.299 \\
(0.234)\end{array}$ & $\begin{array}{c}-1.017 \\
(0.335)^{* * *}\end{array}$ & $\begin{array}{c}0.326 \\
(0.363)\end{array}$ & $\begin{array}{c}1.103 \\
(1.734)\end{array}$ & $\begin{array}{c}-0.960 \\
(0.527)^{*}\end{array}$ & $\begin{array}{c}0.343 \\
(0.343)\end{array}$ & $\begin{array}{c}0.232 \\
(0.376)\end{array}$ \\
\hline$z_{t, F R}^{*}$ & -0.575 & 0.439 & -2.004 & -3.485 & 1.080 & -0.094 & -0.174 \\
\hline$z_{t, I R}^{*}$ & $\begin{array}{c}(0.311)^{*} \\
-0.133 \\
(.087)\end{array}$ & $\begin{array}{c}(0.441) \\
-0.206 \\
(0.126)\end{array}$ & $\begin{array}{c}(0.482)^{* * *} \\
0.302 \\
(0.135)^{* *}\end{array}$ & $\begin{array}{c}(2.303) \\
-3.173 \\
(0.648)^{* * *}\end{array}$ & $\begin{array}{c}(0.699) \\
-0.386 \\
(0.196)^{*}\end{array}$ & $\begin{array}{c}(0.456) \\
0.117 \\
(0.128)\end{array}$ & $\begin{array}{c}(0.535) \\
-0.265 \\
(0.142)^{*}\end{array}$ \\
\hline$z_{t, I T}^{*}$ & $\begin{array}{c}0.095 \\
(0.193)\end{array}$ & $\begin{array}{c}0.166 \\
(0.275)\end{array}$ & $\begin{array}{c}0.630 \\
(0.300)^{* *}\end{array}$ & $\begin{array}{c}3.931 \\
(1.434)^{* * *}\end{array}$ & $\begin{array}{l}-0.314 \\
(0.435)\end{array}$ & $\begin{array}{l}-0.371 \\
(0.284)\end{array}$ & $\begin{array}{c}0.138 \\
(0.365)\end{array}$ \\
\hline$z_{t, N L}^{*}$ & $\begin{array}{c}0.293 \\
(0.338)\end{array}$ & $\begin{array}{c}-0.182 \\
(0.481)\end{array}$ & $\begin{array}{l}-0.219 \\
(0.524)\end{array}$ & $\begin{array}{c}2.131 \\
(2.505)\end{array}$ & $\begin{array}{c}-0.275 \\
(0.761)\end{array}$ & $\begin{array}{c}-1.048 \\
(0.496)^{* *}\end{array}$ & $\begin{array}{c}0.360 \\
(0.548)\end{array}$ \\
\hline$z_{t, U S}^{*}$ & $\begin{array}{c}0.086 \\
(0.137)\end{array}$ & $\begin{array}{c}0.016 \\
(0.198)\end{array}$ & $\begin{array}{c}-0.054 \\
(0.212)\end{array}$ & $\begin{array}{c}-0.295 \\
(1.015)\end{array}$ & $\begin{array}{c}-0.201 \\
(0.308)\end{array}$ & $\begin{array}{l}-0.176 \\
(0.201)\end{array}$ & $\begin{array}{c}0.058 \\
(0.234)\end{array}$ \\
\hline$R^{2}$ & 0.265 & 0.185 & 0.182 & 0.536 & 0.041 & 0.183 & 0.120 \\
\hline$B P(12)$ & $\begin{array}{r}10.943 \\
(0.533)\end{array}$ & $\begin{array}{r}11.222 \\
(0.510)\end{array}$ & $\begin{array}{r}11.960 \\
(0.448)\end{array}$ & $\begin{array}{c}5.151 \\
(0.952)\end{array}$ & $\begin{array}{c}10.274 \\
(0.591)\end{array}$ & $\begin{array}{r}16.894 \\
(0.153)\end{array}$ & $\begin{array}{r}10.424 \\
(0.578)\end{array}$ \\
\hline$A R C H(4)$ & $\begin{array}{c}2.242 \\
(0.691)\end{array}$ & $\begin{array}{c}0.634 \\
(0.959)\end{array}$ & $\begin{array}{c}0.649 \\
(0.957)\end{array}$ & $\begin{array}{c}1.936 \\
(0.747)\end{array}$ & $\begin{array}{l}12.600 \\
(0.013)\end{array}$ & $\begin{array}{c}6.527 \\
(0.163)\end{array}$ & $\begin{array}{c}3.786 \\
(0.435)\end{array}$ \\
\hline
\end{tabular}

Notes: See notes in Table 2 for explanation of table. The vector autoregression (VAR) order $j$ of the system is three. For the short-run parameters (lagged first differences in interest rates), the coefficient estimate given is the sum of lagged coefficients and the marginal significance of the $F$ statistic that all lagged coefficients are jointly zero is given in parentheses. For the long-run variables (error correction terms), the numbers in parentheses are the standard errors of the coefficient estimates.

$R^{2}$ is the adjusted coefficient of determination.

$B P(12)$ is the Box-Pierce $Q$ - test statistic for autocorrelation of order 12 in the regression residuals. Marginal significance levels are given in parentheses.

$A R C H(4)$ is Engle's LM test for ARCH effects of order 4

The superscripts ${ }^{* * *},{ }^{* *},{ }^{*}$ indicate statistical significance at the $1 \%, 5 \%$, and $10 \%$ significance levels, respectively. 